\title{
Giving Voice: Utilizing Critical Race Theory to Facilitate Consciousness of Racial Identity for Latina/o College Students ${ }^{1}$
}

\author{
Alison Cerezo \\ San Francisco State University \\ Benedict T. McWhirter, Diana Peña, Marina Valdez, Cristina Bustos \\ University of Oregon
}

\begin{abstract}
The purpose of this manuscript is to describe the development and implementation of the Latina/o Educational Equity Project (LEEP), a pilot program designed to facilitate critical consciousness of race in higher education for Latina/o college students. Consistent with our values in social justice, we developed LEEP with the belief that increased critical consciousness would result in students' recognition of the power dynamics at work in predominately White universities (PWI), increased strength and resilience in being able to negotiate such a context, and improved ability to make the connection between college completion to the upward mobility of their local communities and communities of origin. Elsewhere we present the specific outcomes of this brief intervention (Cerezo \& McWhirter, 2012); our focus here is to describe how we used Critical Race Theory (CRT) as a guiding framework to develop various aspects of the program that we implemented in three PWI settings.
\end{abstract}

Keywords: college students; Latino; critical consciousness; critical Race Theory; cultural congruity

\section{Introduction}

Given that Latinas/os are the fastest growing ethnic group in the United States, expected to reach $29 \%$ of the population by 2050 (U.S. Census Bureau, 2011), educational attainment amongst Latinas/os has significant implications for the nation's social and economic health. Unfortunately, only $13.2 \%$ of Latinas/os in the US have completed an undergraduate degree as compared to $52.3 \%$ of Asian and Pacific Islanders, $29.9 \%$ of Whites, and $19.3 \%$ of Blacks and

1 Tod Sloan was the action editor for this article. 
African Americans (U.S. Census Bureau, 2011). These numbers are especially troublesome because compared to the general population, Latinas/os are more likely to report that earning a college degree is important for 'getting ahead in life' (Pew Hispanic Center, 2009). Thus, factors outside of academic motivation, like cultural factors and access to critical campus resources (Cerezo \& Chang, in press), likely impact many Latina/o students' educational attainment.

The body of literature supports that there are cultural values shared among many Latinas/os. These shared values are important to consider in the development of college programs to support Latina/o student success because many students attend Predominately White Institutions (PWI) where their cultural values are neither recognized nor honored (Chang, 2002; Hurtado, Milem, Clayton-Pederson, \& Allen, 1996; Nuñez, 2009; Reid \& Radhakrishnan, 2003). A key cultural value often associated with Latina/o college students is familismo, which is defined as a strong identification and attachment to one's primary relations, such as family and peers, that is expressed by feelings and behaviors that reflect loyalty and solidarity to one's primary relations (Fuligni \& Pedersen, 2002; Marín \& Marín, 1991; Sabogal, Marín, OteroSabogal, \& Marín, 1987). It is important to consider how the centrality of family impacts Latina/o students within the college environment, which is known to place value on student's individuation as evidenced by increased independence and separation from one's family (Tinto, 1975). Consistent with the development of the Latina/o Educational Equity Project (LEEP), familismo underlies and explains the importance of building community and support on college campuses. For example, increasing the number and depth of one's peers and close relations on campus is key to building both a 'campus family' as well as to helping students learn mechanisms to garner peer support and navigate the cultural norms and practices that are common in higher education (Villalpando, 2004; Yosso, Smith, Ceja, \& Solórzano, 2009).

For many Latinas/os, common cultural norms that drive attitudes and behavior, including degree completion, are further defined by gender. One term often used to describe Latino men is machismo, which involves characteristics of masculinity that include being controlling, emotionally restrictive, and authoritarian (Cervantes, 2006). Torres, Solberg, and Carlstrom (2002) report that until recently, the research literature in the U.S. has promoted a narrow characterization of Latino men as "hyper masculine" without any reference to positive masculinity qualities. In response, the cultural term caballerismo has become the counterpart to machismo to describe characteristics of Latino masculinity that include emotional responsiveness, honor, caretaking and providing for one's family (Arciniega, Anderson, TovarBlank \& Tracey, 2008). For many Latino men, degree completion represents an opportunity to not only bring honor and pride to the family, but also the ability to provide financial support (Campa, 2010; Hernandez, 2000; Zell, 2010). However, these gender roles may also interfere with academic success as the importance of providing for family can often conflict with the financial demands of college.

The cultural term most often used to describe Latinas in the psychology literature is marianismo, which has been commonly defined as female gender role socialization that encourages women to prioritize family to the point of self-sacrifice (Gil \& Vasquez, 1996; Ginorio \& Martinez, 1996) and involves characteristics like virtue, humility, and nurturance (Castillo, Perez, Castillo, \& Ghosheh, 2010). Although marianismo may be useful in understanding the gender role socialization that many Latinas endorse, it is important to consider how this cultural term has been used to offer a very limited narrative of Latinas' lived 
experiences (Cerezo \& Peña, in press). Arredondo (2002) states that Latinas' identity development is intricately tied to overlapping oppressions related to gender, ethnicity, and social class in both the United States and Latin America. With that said, marianismo is primarily described in relation to the family. However, these attributes within the college context may involve Latinas taking on particular relational roles such as caretaking with close counterparts and peers, or assuming these roles at home, which may interfere with degree completion.

Researchers have identified important factors that support Latinas/os higher educational pathways, which include parental support for education (Arellano \& Padilla, 1996; López, 2001; Ojeda, Navarro, \& Morales, 2011; Sánchez, Reyes, \& Singh, 2006) and mentoring (Bordes \& Arredondo, 2005; Santos \& Reigadas, 2002). However, fewer studies have focused on the cultural climate that exists on some campuses related to racial and ethnic identity, and how negative climates pose significant barriers to student success. Even fewer studies have explored the development of programs designed to support Latina/o students' academic and social adjustment to college, with special attention given to the unique social, historical, and political factors that impact Latinas/os' participation in higher education. The purpose of this paper is to describe the development and implementation of the Latina/o Educational Equity Project (LEEP), a program born out of partnerships with local student and community members, grounded in Critical Race Theory, and developed with the intent of improving student academic and personal experiences by facilitating critical consciousness of race in higher education, building student campus social connections, and improving student utilization of campus support programs.

\section{Review of the Literature}

\section{Campus Climate at Predominately White Institutions (PWIs)}

LEEP was specifically designed to meet the needs of Latina/o students at PWIs in Oregon, the authors' state of residence at the time this project was completed. To understand the gravity of the issues and needs of Latina/o students at PWIs, it is first important to review the research on campus climate at PWIs. Racial and ethnic diversity greatly shapes institutional climate and plays an influential role in racial-ethnic minority student social adjustment and persistence in college. It is evident in the research that students of color perceive university environments as more hostile and unfriendly than White students (Chang, 2002; Gloria \& Rodriguez, 2000; Hurtado et al., 1996; Nuñez, 2009; Reid \& Radhakrishnan, 2003; Yosso et al., 2009). Hurtado et al. proposed a model of campus diversity environment/climate that is influenced by the following factors: (a) historical legacy of inclusion or exclusion of groups, (b) numerical representation of diverse people, (c) nature of interactions among diverse groups, and (d) individual perceptions of campus climate. Furthermore, Chang described PWIs as locations "whose prevailing norms, values, and practices cater mostly to white students even though the total enrollment may have a small percentage of students of color as well as foreign students" (p. 2). Students of color at PWIs are likely to face unique challenges that stem from the shear lack of diversity representation. Students may experience more challenges with negative racial experiences and micro aggressions, while also being underrepresented on campus, thereby diminishing their ability to effect change within the university climate. 
Historically, students of color have reported more negative perceptions of campus climate than their White peers (Harper \& Hurtado, 2007; Hurtado, 1992) and these perceptions have been associated with lower academic achievement and persistence (Hurtado et al., 1996), poorer self-esteem (Reid \& Radhakrishnan, 2003), and a diminished sense of belonging (Nuñez, 2009). Nuñez found that experiencing a hostile climate was the strongest and most negative predictor of whether or not Latina/o students had a sense of belonging in the college environment. In fact, experiencing a hostile climate was a stronger predictor of sense of belonging for students than positive experiences such as having a faculty member take interest in them, higher frequency of positive cross-racial interactions on campus, and higher number of hours they worked per week.

Related to campus climate, Gloria and Robinson-Kurpius (1996) applied the concept of cultural congruity to describe 'cultural fit' - or student perceptions of how their personal and cultural values 'fit' with the prevailing values of the college setting. Researchers have found that cultural fit matters for Latina/o college students, particularly with respect to psychological wellbeing, increased persistence to graduation (Gloria, Castellanos, \& Orozco, 2005; Gloria, Castellanos, Scull, \& Villegas, 2009), sense of belonging (Bordes \& Arredondo, 2005) and college GPA (Cerezo \& Chang, in press). Cultural congruity was a key component of LEEP, with the intention of increasing student ability to critique and understand a lack of fit with their university as a normative response when the institution does not reflect their values. In addition to critiquing and understanding campus climate, another key component of LEEP focused on promoting social support. The next section provides empirical evidence of the importance of peers and how promoting social support is essential in campus programming for Latina/o students at PWIs.

\section{Protective Role of Peer Community}

Given the importance of belonging and community for Latina/o student retention, success, and well-being, a key goal of the LEEP intervention was to increase student social support networks. As supported by the research literature, peers are essential to student post-secondary aspirations and experiences because they provide "students with the social capital to know what is valued and expected of them" (Wells et al., 2011, p. 3). Additionally, Rodriguez, Mira, Myers, Morris, and Cardoza (2003) found that Latinas/os perceive higher rates of support from peers than family members, and that peer support was associated with positive well-being and protected against feelings of distress. More aligned with the goal of our program, to specifically develop ethnically similar communities, Museus (2008) found that African American and Asian American student involvement in ethnic student organizations was instrumental to their adjustment to college at PWIs. Namely, ethnic student organizations provided a space for students to engage in cultural expression and receive validation in their cultural identity. Villalpando (2003) found similar results for Chicana/o college students; an ethnically similar peer community provided cultural resources to navigate the university, which in turn helped students to feel more connected to their university environment.

An added benefit of having an ethnic similar peer network is that such community provides cultural validation that allows marginalized students to think more critically about the campus environment, that is, to become more critically conscious (Freire, 1970). In response to Tinto's (1993) commonly used theory of college student development, Yosso and colleagues (2009) 
described a counter developmental trajectory that accounts for how students of color often navigate racial campus climate. In their review of the literature, Yosso et al. found that as a result of having to confront "incessant, subtle, yet stunning racial assaults, or micro aggressions" (p. 660) in the campus setting, many students of color form 'counterspaces' comprised of supportive peers where they are able to gain validation and critical skills to navigate the campus climate. Counterspaces are physical and/or social spaces that symbolize opportunities for individuals from historically marginalized communities to receive cultural validation. For example, González (2002) described how two Chicano dorm mates used Chicana/o art on their walls, Chicana/o music, Spanish language, as well as participating in Chicana/o studies classes and events to form a physical and social space on campus where they could receive validation of their Chicana/o identity. It is in these counterspaces that many students of color gain the language and skills to identify oppressive conditions within the university and make efforts to rectify such oppression (Solórzano \& Yosso, 2001). In developing LEEP, one goal was to provide such a counterspace to facilitate students' social support, especially with other Latina/o students.

\section{Utilization of Campus Resources}

Although peer support has proven integral for many students of color to have the ability to navigate the rough waters present at many PWIs, research has also noted the importance of social connections with university staff and faculty members (Bordes \& Arredondo, 2005; Cunningham, Cardenas, Martinez, \& Mason, 2006; Thile \& Matt, 2005). A key component of LEEP involved increasing the utilization of campus resources to improve achievement and retention of Latina/o college students. In an evaluation of a retention program with Latina/o undergraduates, Santos and Reigadas (2002) found that greater frequency of contact with a faculty mentor was associated with college self-efficacy, better-defined academic goals, and a higher level of concern to perform well and meet academic obligations. It can therefore be assumed that students would benefit from seeking out support when campus resources are, in fact, culturally sensitive and able to meet students' academic and personal needs. Related to campus climate and racial micro aggressions, Muñoz (1986) found that Latina/o students experience more personal stress than White peers when they seek out support for academic and/or personal needs. In the Muñoz study, Latina/o students' stress levels was related to perceptions that others believed they were not academically skilled and thus did not belong on campus; seeking help was thought to confirm these negative judgments. The result of many of these factors is Latina/o students are often more comfortable seeking out family members and peers than formal counseling for personal issues (Chiang, Hunter, \& Yeh, 2004; Constantine, Wilton, \& Caldwell, 2003). This has important implications for campus programming to enhance peer networks for Latina/o students.

\section{Background}

LEEP was developed in partnership with student and local community members who identified the need to improve rates of degree completion among Latino students. These partnerships were developed out of the first author's active involvement in campus activism prior to the development of LEEP. In order to provide context, a description of the campus climate at a PWI during the time in which partnerships were developed is provided. 


\section{Local Context}

For approximately three years leading up to the development and implementation of LEEP, university students and local community leaders were actively engaged in advocacy concerning the campus climate for students of color at University A. University A is a large public university in the Pacific Northwest with a student body of approximately 22,000. The campus is a PWI where Latinos comprise $3.8 \%$ of the student body. Many incidents of bias occurred at University A against culturally diverse students, and in addition, local community members strongly expressed concern that students were receiving inadequate preparation to work with underserved populations. Numerous meetings and demonstrations were organized to address these concerns. Below is an announcement for a student gathering during this time:

A recent upsurge in bias incidents and the lack of administrative commitment to an adequate diversity plan has created a hostile campus climate. This Tuesday, May $2^{\text {nd }}$ (2006), concerned students are coming together to move forward on diversity action. This meeting will work as a town hall and will serve to gather issues/concerns that matter to you and your communities and your ideas for how to make positive change.

Although these events occurred at University $A$, the political educational climate permeated throughout the region and received national media coverage. The rise in organizing on campus and local community was consistent for several years and resulted with a college-wide diversity plan along with a change of appointments for university administrators, including the replacement of a dean of a major college at University $A$. The first author was actively engaged in these efforts via student and community activism. The pilot intervention program, LEEP, was originally created to improve campus climate for Latina/o students at University A, and so emerged from this political and ecological context.

A central community leader who was actively engaged in these political efforts served on the first author's dissertation committee (non-voting member because of lack of doctorate) and played a key role in the development and implementation of LEEP. Specifically, he recommended connections for the first author to gather additional community member insight, and connected the first author with sister universities ( $B$ and $C$ ) for wider implementation of the pilot program. His feedback on LEEP was, although not purposefully, informed by his involvement in local political efforts. The other university sites ( $B$ and $C$ ) were chosen for their regional access to the research team (within a 70 mile radius) and their similarity in racial composition of the student body and surrounding community-given that we developed LEEP with the assumption that campus racial climate was a challenge facing many Latino students attending PWIs.

The infusion of Critical Race Theory for such a multicultural program seemed appropriate for the campus and community dynamics at Universities B and C. Our assumptions were confirmed by multicultural and residential staff and student leaders at the sister schools who collaborated with us to deliver LEEP to their campuses. University B is a large, public PWI campus with a student body of approximately 22,000, where Latinos make up $3.8 \%$ of the student body. University $C$ is a small PWI public university campus with a student body of approximately 6,200 where Latinos comprise $3.3 \%$ of the student body. 


\section{About the Authors}

Alison Cerezo, Diana Peña, Marina Valdez, Cristina Bustos were students in a Counseling Psychology doctoral program at University A during the implementation of LEEP. Benedict McWhirter (second author) is a professor in the same program and was the dissertation advisor to Alison Cerezo, the first author of this paper. Alison, Diana, Marina, and Cristina identify as Latinas and Benedict identifies as European American. All authors were raised in a predominately Latino region of the U.S. (Southern California, Arizona, and Texas), speak Spanish fluently, and have been actively involved in Latina/o mental health through research and practice for a number of years.

The authors participated in the development and implementation of LEEP with the desire to improve the campus experiences of Latina/o students in the Pacific Northwest. Given that each of us was raised in a predominately Latino region, those of us who were doctoral students at university $A$ experienced some of the challenges associated with navigating a PWI when we began attending University $A$. Though our graduate program was much more diverse and had a student group whose purpose was to support the retention of students of color, we were each personally affected by the campus climate and wanted to contribute to efforts that would help support Latino undergraduates. We piloted LEEP with the following assumptions: (a) students would face some negative experiences in relation to race and ethnicity in college and/or the local community, (b) students would endorse some degree of familismo, and (c) students had a limited degree of support on campus given the few formal resources available and the low numbers of students of color in the student body.

\section{Theoretical Framework}

Critical Race Theory (CRT) was used as the guiding framework for the creation and delivery of our pilot program. CRT emerged in the 1970's as an outgrowth of Critical Legal Studies, a movement comprised of legal scholars who wanted to expose how customary legal ideology and practices, based on American values of meritocracy and fairness, served to maintain oppressive structures in American society (Delgado \& Stefancic, 2001; Ladson-Billings, 1998; Solórzano \& Delgado Bernal, 2001; Solórzano \& Yosso, 2001). CRT was a product of the critical legal studies movement by adding race and racism to the dialogue. Thus, CRT provided a framework to consider how common legal doctrine, policies, and practices served to maintain systems of racial inequity by not considering how deeply embedded racism was in American history and social order. A central goal of CRT was to facilitate insightful critiques of racial inequality in the legal system so that meaningful, thoughtful action to rectify such oppression could be developed.

CRT has important implications for counseling, particularly within educational settings. Chiang, Hunter, and Yeh (2004) found that Latina/o college students were more likely to turn to a friend, parent, or significant other than talk with a professional counselor, while Constantine, Wilton, and Caldwell (2003) found that Latina/o college students with higher social support satisfaction were less willing to seek professional counseling. These findings may be related to both familismo (centrality of primary relations like family and close friends) as well a lack of cultural validation (Yosso et al., 2009) that many students of color experience within 
educational settings. Goodman and West-Olatunji (2010) describe how systemic racial oppression permeates educational settings, which then leads to traumatic stress for many students of color. The authors particularly note how traumatic stress that is often faced by Latina/o and African American students in educational settings contributes to underachievement behaviors (e.g. disengagement in school, difficulty concentrating). Goodman and West-Olatunji recommend that counselors help students work toward ameliorating traumatic stress by facilitating recognition (consciousness) of traumatic events and aiding students to develop mechanisms that will help them gain power over these events, such as sharing autobiographies or skits that can be shared before the school community.

As it pertains to education, CRT has been identified as a useful framework to critique educational policies and policy-making within a historical and cultural context, as well as analyze racial exclusion and other forms of discrimination against students (Ladson-Billings, 1998; Taylor, 1998; Solórzano \& Delgado Bernal, 2001; Villalpando, 1994). Education scholars advocate for the importance of considering historical events and interactions between communities and schools; for example, how many students of color attend academically underresourced schools and are tracked into non-college preparatory courses, in addition to other factors that hinder students' ability to successfully attain a college degree (Villalpando, 2004). Thus, examining Latina/o educational performance takes context into consideration by critiquing how historical policies and practices have negatively impacted student success.

CRT scholars emphasize five critical components related to higher education that center on challenging dominant ideology in university settings. Namely, exploring how university practices that cater to a color-blind and race-neutral approach serve to minimize the existence of racism and the consequent negative impacts on the educational outcomes of students of color (Villalpando, 2004). Such minimization thwarts efforts to improve university practices that respond to the unique needs of students of color and contribute to their retention.

We sought to "give voice", a hallmark component of CRT (Ladson-Billings, 1998), by including Latina/o students and community members throughout the development and delivery of our program. We sought input by working with students, community leaders, and multicultural and residential life staff (primarily people of color) to learn the history and challenges facing Latina/o students in the surrounding area, as well as methods they believed would best address the identified needs (e.g. cultural fit, increased utilization of campus resources). Further, the first author sought consultation regarding recruitment and data collection from local student communities, including their history with the university from which the authors were affiliated, in an effort to be sensitive to unique issues and needs at each campus.

Taking from CRT, we sought to develop a program that was grounded in the identified needs of the surrounding area, had community "buy-in" and access, and thus had the potential to make positive, systemic change for the local area. Our hope was that LEEP would be the first of many retention initiatives for students of color, and that critical analyses of the roles that race and racism play in college achievement would be incorporated in these efforts. Below is a description of the five critical components followed by an explanation of how CRT was reflected in the LEEP intervention: 
1. Centering examinations of race and racism within university structures, practices, and discourse. Recognition that race and racism are inextricably linked to the history and continued development of American life and are thus embedded in important domains, including college settings.

2. Challenge to dominant ideology. Dominant ideology has been described as "traditional claims of universities to objectivity, meritocracy, color blindness, race neutrality, and equal opportunity" (Villalpando, 2004, p. 44). CRT can thus be used to critique such ideology that dominates popular belief systems of higher education.

3. Commitment to social justice and praxis. An action component; a commitment to rectifying racial inequality within important areas of life, such as educational systems.

4. Honoring experiential knowledge from people of color. Recognition that persons of color hold critical knowledge from their lived experiences with negotiating ethnic and racial minority identities in the U.S., and that this knowledge is imperative to success in important domains of life, such as higher education.

5. An historical context and interdisciplinary perspective. Recognition that students initiate and interact with educational systems based on their cultural and social contexts.

\section{Program Description}

Informed by our conversations with community leaders and review of the research literature, we developed LEEP with the assumption that a key challenge facing many Latina/o students was the campus racial climate; that navigating predominately White spaces with long-standing, negative racial climates for students of color impacted their educational and social progress (Chang, 2002; Harper \& Hurtado, 2007; Hurtado et al., 1996; Reid \& Radhakrishnan, 2003; Villalpando, 1994; 2004; Yosso et al., 2009). Four key components of LEEP were carefully couched within tenets of CRT and included (a) building a supportive community, (b) increasing consciousness regarding race and (c) cultural congruity in higher education, and (d) developing skills to identify supportive, effective resources on the college campus to handle potentially challenging situations. Each of these components was developed in response to needs that were identified in conversations with university personnel and student leaders at the three university sites. For example, a staff person at University B identified the need for Latina/o students to improve their knowledge and comfort with utilizing campus resources, while university personnel and student leaders at University $\mathrm{C}$ identified the need for Latina/o students to improve their skills with developing a supportive peer network. The format of the program was influenced by resources available related to funding, the location of the universities, and in consideration of programming that was already available at the three target campus sites.

\section{Building Community}

The first section of the program was geared toward helping students build a network of peers who support their academic and social potential while integrating their racial, ethnic experiences as Latina/o students. As demonstrated in the research literature, peer support and more specifically ethnically similar peer support, plays an important function for many Latina/o college students because it models to students how to navigate the academic and social demands of 
college and provides space for cultural validation, which then improves students' sense of belonging (Hernandez, 2002; Museus, 2008; Rodriguez et al., 2003; Villalpando, 2003).

In LEEP, 'building community' was achieved by cultivating interpersonal connections between students and having students explore where they receive encouragement to attend college and succeed in college, as well as emotional, facilitative and financial support in relation to their educational endeavors. Also, participants discussed mechanisms for improving their social network to advance their retention in college. Building on previous research and tenets of CRT, the goal of this section of LEEP was to assist students with (a) developing and/or improving their current support system to effect positive outcomes toward their academic goals, and (b) recognizing how ethnically similar peers (LEEP participants) have critical knowledge to share when it comes to effectively negotiating the social and educational demands that come with attending a PWI.

\section{Increasing Critical Consciousness}

The second section of the program focused on critical consciousness, specifically, facilitating students' persistence in college as a result of political consciousness of being an ethnic and/or racial minority student in higher education. Critical consciousness is the ability to perceive oppression within social, political, and economic realms and to encourage others to take action against oppressive systems (Freire, 1970). As found by Yosso et al. (2009), many Latina/o students gain the skills needed to navigate university by learning to confront incessant, often subtle, racial micro aggressions that question their belongingness on campus. The authors found that students were better able to recognize micro aggressions, which lead to building defenses against internalizing these negative messages. Further, students reported gaining power in 'proving others wrong' via overcoming others' perception by high achievement in college.

As demonstrated by Museus (2008), Villalpando (2004), and Yosso et al. (2009), critical consciousness is often facilitated in ethnically similar peer communities because these 'counterspaces' allow students to think more critically about the university context and recognize how oppression operates within higher education. Thus, students are then able to develop the capacity to critically assess the university environment and build defenses against messages and practices that imply that their lived experiences, as Latinas/os, are less valued. We, along with the university personnel and student leader consultants, identified the importance of facilitating critical consciousness for project participants in two manners.

First, by facilitating students' ability to critique their institutions so that a "lack of fit" could be seen as not solely centered in the individual but more so having to do with the historical, racial climate of their university (Chang, 2002; Harper \& Hurtado, 2007; Hurtado et al, 1996). Thus, a lack of fit could be understood as a normative response to a university setting that did not center or reflect the lived experiences of students of color. Second, we intended to stress the importance of college completion as a mechanism for supporting the general needs of the Latino/a community. In a qualitative study of Mexican-American community college students, Campa (2010) found that students' academic motivation was partially fueled by critical resilience that included desires to uplift their home communities. The author described this process as, "experiencing inequitable treatment engenders in the students a deep desire to 
change the conditions in society that give rise to this marginalization" (p. 440). Thus, connected to previous findings and aligned with CRT, we conceptualized college completion for this group as a means toward social justice and praxis; Latina/o college graduates with gained consciousness of cultural identity have the capacity to effect significant, positive change to improve conditions in the local community for other Latinos/as and underserved populations.

\section{Improving Awareness of Cultural Congruity}

The third section of the program was focused on facilitating participant awareness of the university as a context that comes with unique values and demands, and that their upbringing prior to university may and/or may not align with these expectations. Many researchers have described university climate as an atmosphere that reflects White, middle-class, male values and histories (Chang, 2002; Gloria, Castellanos, \& Orozco, 2005; Harper \& Hurtado, 2007; Hurtado, 1992; Hurtado et al., 1996; Yosso et al., 2009). Though our conceptualization of university climate is in line with this description, our intent was solely to point out that universities are cultural contexts that often expect a unique set of values and behaviors to achieve success, and that students may or may not come to campus with an understanding or ability to perform to these expectations.

Consistent with Torre's (2008) application of CRT to social science research, we were cognizant that students came with "multiple, overlapping, potentially conflicting, identities, loyalties, and allegiances" and that a sizeable portion of the group emerged from predominately White communities and had likely integrated many majority cultural values in their lives. Thus, this section of the program was focused on facilitating participants' understanding of the similarities and/or differences that they experience between their university and home environments, and to critique how the university could better serve their needs. Similar to the goal of the critical consciousness section of our program, we set out to make known that a "lack of fit" with the university environment was often a normative response to a setting that often does not centralize Latina/o and other culturally diverse student experiences.

\section{Improving Utilization of Campus Resources}

The fourth and final section of the program was focused on maximizing students' interaction with the campus community. Our goal was to end the program with praxis - imparting students with a specific skill they could use to improve their access to critical resources while effecting change in the campus climate via increased interaction with important areas of the university setting (e.g. financial aid, academic programs, counseling centers, etc.). This segment of the intervention was developed based on research literature that demonstrate (a) the challenges many Latina/o students experience with seeking out support through campus programs and/or talking with faculty (Constantine, Wilton, \& Caldwell, 2003; Chiang, Hunter, \& Yeh, 2004; Muñoz, 1986) and (b) the benefits students experience when they receive culturally sensitive support from faculty or university personnel (Bordes \& Arredondo, 2005; Cunningham, Cardenas, Martinez, \& Mason, 2006; Santos \& Reigadas, 2002; Thile \& Matt, 2005). In recognizing the significant challenges many Latina/o students experience with seeking out campus resources, the purpose of this section of the intervention was to help students identify 
resources, learn skills to access them, and rely on peers' feedback about services that were culturally sensitive to Latina/o students.

Students were provided with vignettes of common college experiences and worked in small teams to problem-solve best solutions. Students were asked to identify campus resources that would aid in the solution of the student problem and that were known to house staff or faculty that was culturally sensitive to Latina/o students' needs. Aligned with CRT, this section of the intervention provided an opportunity for students to actively learn from one another's campus experiences. Following the completion of the small group activity, the facilitator led a large group conversation regarding campus resources broken down into four categories: academic support, social support, financial support, and miscellaneous support (i.e. technology, residency, food, etc.). The group discussed mechanisms for engaging positively with identified resources based on their experiences, for example, how to speak with a professor, important questions to ask your financial aid advisor, and how and when to speak with a counselor. Embedded in CRT, LEEP ended by relying upon students' experiential knowledge as the high point of the program; the intent was to develop skills that were grounded in other Latina/o students' own lived experiences.

\section{Program Implementation, Review, and Future Directions}

As stated previously, the purpose of this manuscript is to describe how we utilized CRT as a theoretical tool to develop and deliver the LEEP program at the three public universities in the Pacific Northwest. A pilot evaluation of the program's effectiveness can be found in Cerezo and McWhirter (2012). In the next sections of this paper, we seek to provide a realistic understanding of how LEEP was carried out by presenting details about the participants, facilitators, and process of the LEEP intervention as it relates to CRT, and to future directions for enhancing Latina/o college student success and persistence.

\section{Participants}

Forty Latina/o college students completed the LEEP program. The age range for students was 18 to 37 years old $(M=20.54, S D=3.16)$ with females comprising $64.2 \%$ of the sample. The majority of students were in their sophomore year in college but given that each university had a small Latina/o enrollment, we recruited students across all classes. The mean GPA was 3.16 $(S D=.54)$ with $79 \%$ meeting the designation of first generation college student. The majority of participants' parents completed less than a high school education (53\%) followed by completion of high school (26\%). The majority of students (78\%) reported citizenship in the United States and $62 \%$ of the sample was employed with an average of $15.37(S D=8.86)$ hours worked per week.

\section{Implementation}

To carry out the program we first met with a community leader with a 20-year history of work on educational equity for Latina/o college students, along with several student leaders. These individuals were connected with University A and were involved in multicultural efforts on that 
campus. Our community contact recommended other individuals to connect with so that we could learn the history of the region (for all universities) as relevant to Latina/o education. Second, we made contact with multicultural student support services at University B and C to learn about the campus racial dynamics and to ensure need existed on the campuses for a program like LEEP. For University B, staff connected the first author with student leaders to gather additional information about the needs of the program and logistics for carrying out the program. On each campus, stakeholders (university staff and student leaders) encouraged the delivery of LEEP at their institution and provided in-kind support with recruitment, reservation of space, food, and miscellaneous needs. Next, we made contact with residential life in order to reach the broadest range of Latina/o students on campus. At University $B$, the staff at residential life connected us with the College Assistance Migrant Program (CAMP) since they identified residents from this group as needing the greatest amount of formal support. The first author worked with the director of CAMP to make certain LEEP augmented their own efforts, and to ensure sensitive methods for recruitment and data collection. The CAMP director actively recruited students for involvement in LEEP.

LEEP was conducted over the course of one day, with a total contact time of eight intervention hours. Each segment of the program was approximately one hour and forty-five minutes that included an introduction to the topic, personal reflection via a written assignment, group sharing, and a conclusion period. The only segment that differed was 'Increasing the Utilization of Campus Resources' where the facilitator led the group in two exercises with follow-up discussions. LEEP was conducted in a group format with 5-10 students in each group. Six separate groups completed the program, two groups from each university campus. The oneday delivery of the intervention was not the original plan. A discussion about the costs and benefits of this delivery change are discussed later in the manuscript.

At the start of the day, students were provided with breakfast and were instructed to complete pre-test measures in silence. The first author and group facilitator for that day were present to answer questions. Upon completion of the measures, the group facilitator took participants to a separate room where the program was held. The first two segments were completed (Building Community, Increasing Critical Consciousness) before the group broke out for lunch. Lunch was served to participants in a separate room that had music playing in the background and where students were encouraged to relax. The first author and group facilitator were present during the lunch break. Upon completion of lunch, participants returned to a separate room to complete the final two sections of the program (Increasing Awareness of Cultural Congruity, Increasing Utilization of Campus Resources). At the end of the day, participants completed a facilitator evaluation form and were provided with directions about completing post-test measures.

\section{Treatment Fidelity}

Three female Latina graduate students in a Counseling Psychology doctoral program served as the facilitators of the program. The program was delivered six times; a sole facilitator ran each group. Facilitators participated in a one-week long training on the program that included theoretical foundations, including CRT and the Ecological Model (Bronfenbrenner, 1979), and practice in implementing the curriculum with culturally specific facilitation skills (Ivey \& Ivey, 2007; Sue, 2003). Themes and skills of LEEP were also congruent with training provided to the 
facilitators in their counseling psychology doctoral program; the program philosophy was centered on the Ecological Model and had strong roots in social justice and advocacy. Each delivery of the program was videotaped to ensure curriculum delivery fidelity. All tapes were reviewed for fidelity, and the authors agreed that all six runs of the program followed the curriculum consistently.

\section{Facilitator And Student Ethnic Match}

The importance of identifiable role models and mentors for students of color is consistent with CRT and the literature on successful intervention programs for Latina/o college students (e.g., Santos \& Reigadas, 2002). Ethnic match was therefore an important element of LEEP because it centralized experiential knowledge of the group facilitators who were people of color. Facilitators of the same racial-ethnic heritage were recruited in order to facilitate a sense of community and to provide positive Latina/o university role models to students. Although the facilitators were not in a formal mentor role, they facilitated conversations based on personal and cultural experiences, including their own, which was an important element of our program design.

\section{Change In Program Delivery}

Originally, the program was conceptualized as four separate sessions, two hours each, set to occur a week apart. We hypothesized that this structure would maximize student learning; there would be ample time for absorption of the information, which would result in increased critical thinking and consequent behavioral change. But in response to financial and logistical limitations, in addition to site preferences, LEEP was provided in one day. More specifically, each university provided financial support via in-kind donations such as reservation of university space, food, and printing of materials for recruitment and data collection. Because each group was conducted with 5-10 participants, expenses proved too costly for the original implementation plan. Also, some university staff requested a decreased duration period because they wanted to be present during the groups (though they were not allowed in the groups for privacy reasons) to learn mechanisms for data collection and to witness the set-up of such a program.

The content of LEEP remained the same, though it was provided in one, as opposed to four sessions. In the end, LEEP became a short-term program that could be more easily replicated than previously intended. Although we hypothesize that student learning and change may have been less than if the program were to have been delivered as originally conceptualized, we held the program in a manner that reflected the needs of the target communities. Thus, the process of delivering LEEP aimed to contribute to positive collaborative relationships with university staff and student leaders, which is important because such relationships increase future opportunities for similar efforts. 


\section{Challenge Of Facilitating Consciousness}

We were careful to be aware of the power we held in relation to undergraduate students, resulting from our access to graduate education and the status of being seen as future psychologists. Systems of power, or power itself, involve the facilitation of "people to actively participate in the judgment of their own and each other's lives according to socially constructed norms" (White, 2002, p.43). The issue of power is especially relevant to Latina/o students attending a PWI, where the common and enforced cultural values and practices on campus are based in White lived experiences, not those of people of color. As described by Fouad and Arredondo (2007) as well as Pinderhughes (1997), the dynamics of difference and power in interpersonal relations have a significant impact on individuals' behaviors, particularly for those who have less power in the relational dynamic, and thus have more to lose if the relation goes awry. A challenge we thus experienced in facilitating students' consciousness was introducing the concepts of critical consciousness, cultural congruity, and university climate, and in doing so, framing students' conceptualizations and applications of these concepts to their lives. We prompted students to personalize the concepts to their life experiences but cannot deny that our introduction of the concepts led students' thinking; our power as doctoral students and alignment with university staff impacted students' processes. Despite this influence, the responses below demonstrate that students connected education to social justice - a college degree was seen as an act, a tool toward advancing important issues in their communities.

\section{Gauging Change In Critical Consciousness}

In the next section we present reflections from a facilitator who ran two groups of the program as well as participants' written responses during certain program exercises. To be clear, we are not attempting to provide evidence of the utility or effectiveness of LEEP but instead to help the reader have a clearer understanding of what occurred during the course of the program.

\section{Facilitator Reflection}

The LEEP program offered Latino students a full eight-hour day to gather and discuss topics related to their lives as Latino students in higher education. As the intervention unfolded, students identified similarities as well as differences in their experiences on campus and in the local community, and in several instances, helped each other understand and apply these concepts to their lived experiences. For example, in a discussion about affirmative action and critical consciousness, a fourth-year student shared her understanding of the concepts as a way to challenge and broaden a first-year student's uncertainty about them. Students were also prompted to discuss their experiences with campus community and campus climate. Through this discussion, students voiced both neutral and negative experiences, including an awareness of xenophobia and "being tolerated", demonstrating critical awareness about sociopolitical issues that impact them. During lunch, students appeared to connect with each other, which was evident as they laughed together, spoke bilingually, and continued to talk about their lives as Latina/o college students. Over the course of the day, students shared stories of perceived discrimination, racism, and oppression on campus; they spoke about feelings of isolation, for example, being the only students of color in their major, or having no mentor of color in their department. They engaged in activities that were novel to some of them, including reflective journaling and the final smaller group task of identifying campus resources and support for a 
hypothetical student. After the intervention ended, students lingered to continue talking with each other, help with clean up, and connect with the project leader and with me as the facilitator.

\section{Students' Written Responses to Program Exercises}

The key function of LEEP was to facilitate students' critical consciousness with regard to racial identity within higher education. Our primary goal was to broaden students' considerations of their campus environment to not only include how students "fit" with the university, but how the university meets their needs by centralizing and reflecting their experiences as students of color. In order for this to take place, a shift in thinking toward an historical and interdisciplinary perspective would need to occur for many students (likely that some came to the program with this line of thinking) - a perspective that considers the contexts and events leading up to college attendance (Solórzano \& Yosso, 2001; Villalpando, 2004). These may include emerging from under-resourced schools, low-income communities with disproportionately high gang activity and violence, and less cultural capital (Coleman, 1988) from family members that can pass down information to access higher education, among other factors. The goal of considering such factors was to help students' recognize their resiliency and strength as college students - that their educational success often included overcoming hardship to arrive to the university, and while at the university, navigating a sometimes unfriendly or hostile campus climate toward members of their ethnic group (Harper \& Hurtado, 2007; Hurtado et al., 1996; Reid \& Radhakrishnan, 2003; Yosso et al., 2009). A related goal was to advance students' motivation toward effecting change in their local communities by making connections between college completion and gaining the necessary resources (academic skills, degree, network) to effect such change (see Campa, 2010).

In this section we present written responses to exercises during the critical consciousness and cultural congruity sections of the LEEP program. The two other sections, building community and campus resources, were activity based, therefore we will not provide written responses. Students were given a prompt to write and discuss how the concepts of critical consciousness and cultural congruity were related to their experiences as Latina/o college students. The responses that we present below are characteristic of answers across all groups to the prompt, "How does critical consciousness relate to your experiences in college?" Students completed written responses before entering a group discussion.

- Participant 1: "Being educated in your heritage and your background is a valuable tool in life-it is like a resource. Knowing where you come from allows you to see what is happening in society to our Gente (people). How can we take this information and use it to instill in others the importance?"

- Participant 2: "Realizing that you are breaking the cycle by getting an education. You are defying the norm."

- Participant 3: "Overall I feel that to Latinos, education is a valuable tool. In society we are still the minority and we should not feel pressured to hide who we are because we are not the 'norm' of being white in advancements of higher education. Education is the tool that will allow us to go out and create a sort of change in society not only for our Gente (people) but those in various communities that we touch through time." 
Many students detailed how education was a tool for them to effect systemic change to improve conditions in their home communities. Facilitators noted that students often discussed the importance of family and how college completion was connected to the upward mobility of the entire family unit. These responses align with familismo (Fuligni \& Pedersen, 2002; Marín \& Marín, 1991; Sabogal, Marín, Otero-Sabogal, \& Marín, 1987) and the perception that degree completion is an accomplishment shared among the family unit (Hernandez, 2000; Zell, 2010). Consistent with Yosso et al. (2009), students also described how attainment of a college degree was an act of social justice, defying common narratives available to them as Latinas/os by seeking upward mobility through higher education.

During the cultural congruity section of the program, students were first prompted into a discussion about trends with interpersonal relationships and work expectations they have noticed in (a) the campus environment, (b) their home environment, and (c) the similarities and differences between these contexts. Facilitators were careful to honor each student's description of their home community. Since students varied in the ethnic makeup and economic layout of their home areas, it was important to honor differences and not assume a shared lived experience across participants. The purpose of the exercise was to help students analyze the university as a context that values and expects particular behaviors, and that for some students who are new to such values and expected behaviors, they may experience difficulty with integrating to the university. Furthermore, facilitators discussed the cultural makeup of most universities and how this makeup impacts the college culture in addition to how many PWIs have not centralized student of color experiences (Chang, 2002; Harper \& Hurtado, 2007; Hurtado et al., 1996). Thus, this exercise was intended to help students recognize that "lack of fit" was tied to a history of the campus environment. The concept of cultural congruity was presented to the students as, "perceptions of the cultural fit between values from one's home environment and values from the university environment" (Gloria \& Robinson-Kurpius, 1996). Students were asked to respond to the following prompts to relate university climate and cultural congruity to their experiences as Latina/o college students.

Prompt A: How does the university climate affect your experiences as a Latino/a student?

- Participant 1: "I feel that it's uncaring. Not many people know you well. It's not hostile or friendly. Uncaring. Indifferent".

- Participant 2: "I get weird looks when I talk on my cell in Spanish".

- Participant 3: "Some teachers won't call on you because they don't expect you to know the answer."

- Participant 4: "People are nice, but not really interested in you."

Across the groups, participants expressed facing racial micro aggressions in social and academic realms related to being Latina/o. Related to social connections, an observation across the facilitators was that participants discussed finding community among their ethnic similar peers and through multicultural student support services. Some students described ethnically similar peers and multicultural staff as their "family" on campus; these connections appeared to provide students with social and academic resources that contributed to their sense of belongingness on campus. 
Prompt B: How do you balance home and university demands?

- Participant 1: "It sucks that I can't be part of campus life because I want to see my family on the weekends."

- Participant 2: "There are people that come to college and it's their life, but I go home a lot and talk to my family all the time, so it's hard to be a part of the group in my dorm."

Many students wrote about difficulties they faced with negotiating demands between family and college settings, particularly how prioritizing family impacted their social life on campus in a negative manner. It has been well established that familismo is a central value for many Latina/o college students that drives academic motivation and behaviors (Campa, 2010; Hernandez, 2000; Zell, 2010). One explanation for these written responses is that many Latina/o students may forego social events that are expected of the general student body in order to spend time with family members and retain close family connections that are important factors in their college persistence (Arellano \& Padilla, 1996; López, 2001; Ojeda, Navarro, \& Morales, 2011; Sánchez, Reyes, \& Singh, 2006).

\section{Intended Benefits of the LEEP Program}

\section{Student benefits}

Consistent with our goal of enacting CRT in the development and implementation of the LEEP program, we sought student input at various stages of our process. With respect to development, the first author met with student groups on each campus to gather specific information about student culture and needs that were fused into each delivery of the LEEP program. With respect to delivery, student leaders helped spread the word about the program and invited the first author to make presentations at campus group meetings.

Since we did not gather data about students' experiences of helping to develop and disseminate the program, we cannot assume any direct benefits to students. However, LEEP participants did appear to take on leadership with getting the program off the ground that was consistent with our goals of enacting CRT. The LEEP program was delivered two times at each campus site (total six runs of the program). An important experience that occurred twice was the proactive involvement of previous LEEP participants during the second offering of the program on their campus. Unbeknownst to our team, previous participants recruited students for the program, arrived to the site of the program offering to volunteer, and came at the end of the program to provide rides home for participants. On one occasion, a LEEP participant phoned the first author three months after the program to ask for advice about leading a group discussion about immigration laws that were impacting educational efforts in the state of Arizona. The participant discussed taking on leadership responsibilities in his student union after his involvement in LEEP and his desire to use skills learned in LEEP to lead a difficult dialogue. Again, because we did not gather specific data about the impact of LEEP on students' leadership and advocacy efforts, we cannot make any causal inferences about the benefits of LEEP in these domains. Our hope is that students were able to grasp the concepts of critical consciousness, campus climate, and cultural congruity, and place their experiences within the larger historical context of Latinas/os in higher education. 


\section{University staff/campus benefits}

A major goal of our project was to collaborate with university staff and administrators so that retention efforts for Latina/o students were in the forefront of campus support efforts. In line with this goal, we worked with campus staff from different departments to discuss the program's content and to provide staff with the program manual and surveys used to assess the effectiveness of LEEP in the targeted domains. Staff was invited to the program space so that they could observe data collection, tracking of students' participation, and meet the facilitators. We also provided the full IRB to all staff members so that they could use this model for future research initiatives. Finally, staff at each campus site was kept informed about staff collaborations across their respective campus like multicultural services, residential life, and programming under the Dean of Students. This was important because programs had to collaborate to provide in-kind support and resources that led to the successful delivery of LEEP. Since we did not gather data about campus partnerships and staff attitudes about the program, there is no way to know the effect of LEEP on campus policies and culture. However, we are hopeful that staff benefitted from exposure to the program manual, data collection techniques and specific measures used, and from collaborative efforts across departments to get LEEP off the ground.

\section{Recommendations for Practice}

Counselors and student support staff should consider using CRT for future retention efforts for students who hold membership in groups that have been historically marginalized on the university campus and in the local community. Such a theoretical foundation challenges the very dynamics that work to oppress such students, and calls for the sharing of power in development and delivery of programs because experiential knowledge of people of color is central to efforts directed to these communities. If possible, future programs should be provided over a longer period of time to allow students with an opportunity to better consider and apply CRT concepts to their lives and strengthen peer social supports. Further, counselors and university staff should allow for such programming to comprise a term-long course to secure and improve necessary resources such as space, allotted time, and participant retention. An additional bonus of a term-long course is that the university is symbolically and tangibly supporting the development of critical consciousness for students of color by allowing students to earn course credit while learning about their history within American higher education, and a variety of critical university survival and success skills.

Based on our experiences of hearing and reading students' responses during the program, we recommend that counselors be cognizant of the significant barriers some Latina/o students experience with respect to micro aggressions in social and academic realms, which among our participants, impacted perceptions of campus climate and sense of belonging. Researchers have found that negative perceptions of campus climate (Reid \& Radhakrishnan, 2003) and low sense of belonging (Nuñez, 2009) negatively impact students' academic success. LEEP participants noted how others' negative perceptions of them as Latina/o students created barriers to social connections and fueled faculty's misperceptions of them as less academically able than non-Latina/o peers. Counselors should therefore be vigilant about the potential micro aggressions experienced by Latina/o students and how negative messages may impact their academic and social success as well as their general mental health. If Latina/o students have 
not had the opportunity to explore micro aggressions in the academic context, they may be mistakenly attributing lack of cultural fit and/or academic success solely to their effort and ability.

\section{Conclusions}

Our experience with carrying out LEEP demonstrates the strong potential for CRT as a theoretical tool that can be applied to campus program development and delivery. The purpose of LEEP was to facilitate critical consciousness of race in higher education; specifically to develop students' ability to analyze cultural experiences in university to better recognize their strength and resiliency to complete college and engage in efforts to contribute to their local communities. We were satisfied with the utilization of CRT as a guiding framework to inform not only the content of the program, but also the processes involved in its creation and delivery. CRT was central to our ability to achieve community "buy-in" and thus work in tandem with stakeholders (university staff and student leaders) that allowed for the program's delivery to needed communities. We see LEEP as the initiation of a longer-term commitment to enhancing the success of Latina/o and other underrepresented college students, and in so doing, reciprocally changing and improving campus environments themselves.

\section{Contact information}

Alison Cerezo, Ph.D., Assistant Professor, Department of Counseling, San Francisco State University, acerezo@sfsu.edu

\section{References}

Arciniega, G. M., Anderson, T. C., Tovar-Blank, Z. G., \& Tracey, T. J. G. (2008). Toward a fuller conceptualization of machismo: Development of traditional machismo and caballerismo scale. Journal of Counseling Psychology, 55, 19-33. doi: 10.1037/0022-0167.55.1.19

Arellano, A., \& Padilla, A. (1996). Academic invulnerability among a select group of Latino university students. Hispanic Journal of Behavioral Sciences, 18, 485-507. doi: $10.1177 / 07399863960184004$

Arredondo, P. (2002). Mujeres Latinas-Santas y marquesas. Cultural Diversity and Ethnic Minority Psychology, 8, 308-319. doi: 10.1037//1099-9809.8.4.308

Bordes, V. \& Arredondo, P. (2005). Mentoring and $1^{\text {st }}$-year Latina/o college students. Journal of Hispanic Higher Education, 4, 114-133. Retrieved from: http://dx.doi.org/10.1177/1538192704273855

Bronfenbrenner, U. (1979). The ecology of human development. Cambridge: Harvard University Press.

Campa, B. (2010). Critical resilience, schooling processes, and the academic success of Mexican Americans in a community college. Hispanic Journal of Behavioral Sciences, 32, 429-455. doi:10.1177/0739986310369322 
Castillo, L.G., Perez, F.V., Castillo, R., \& Ghosheh, M.R. (2010). Construction and initial validation of the Marianismo Beliefs Scale. Counseling Psychology Quarterly, 23, 163-175. doi: $10.1080 / 09515071003776036$

Cerezo, A., \& Chang, T. (in press). Latina/o achievement at predominantly White universities: The importance of culture and ethnic community. Journal of Hispanic Higher Education.

Cerezo, A., \& Peña, D. (in press). Feminism as a tool to connect Latinas to graduate psychology training. Women in Therapy.

Cerezo, A., \& McWhirter, B.T. (2012). A brief intervention designed to improve social awareness and skills to improve Latino college student retention. The College Student Journal, 46, 867-879.

Cervantes, J. M. (2006). A new understanding of the macho male image: Exploration of the Mexican American man. In M. Englar-Carlsen \& M. A. Stevens (Eds.), In the room with men: A casebook of therapeutic change (pp. 197-224). Washington, DC: American Psychological Association.

Chang, M.J. (2002). Racial dynamics on campus: What student organizations can tell us. About Campus, March, 2-8. Retrieved from: http://www2.myacpa.org/publications/about campus

Chiang, L., Hunter, C.D., \& Yeh, C.J. (2004). Coping attitudes, sources, and practices among Black and Latino college students. Adolescence San Diego, 39, 793-815.

Coleman, J. S. (1988). Social capital in the development of human capital: The ambiguous position of private schools. American Journal of Sociology, 94, 95-120. Retrieved from: http://www.jstor.org/action/showPublication?journalCode=amerjsoci

Constantine, M.G., Wilton, L., \& Caldwell, L.D. (2003). The role of social support in moderating the relationship between psychological distress and willingness to seek psychological help among Black and Latino college students. Journal of College Counseling, 6, 155-165. Retrieved from: http://collegecounseling.org/resources/journal

Cunningham, P.D., Cardenas, J., Martinez, R. \& Mason, M.L. (2006). Lucero: Shining a light on Latino student retention. Community College Journal of Research and Practice, 30, 139-140. Retrieved from: http://taylorandfrancis.metapress.com/link.asp?target=contribution \&id=P36H35H21260NM36

Delgado, R. \& Stefancic, J. (2001). Critical Race Theory: An Introduction. New York: NYU Press

Fouad, N.A., \& Arredondo, P. (2007). Introduction to multicultural-centered practices. In N.A. Fouad \& P. Arredondo, Becoming culturally oriented: Practical advice for psychologists and educators (p. 313). Washington D.C.: American Psychological Association.

Freire, P. (1970). Pedagogy of the oppressed. New York: The Continuum Publishing Company.

Fuligni, A. J., \& Pedersen, S. (2002). Family obligation and the transition to young adulthood. Development Psychology, 38, 856-868. doi: 10.1037/0012-1649.38.5.856

Gil, R. M., \& Vazquez, C. I. (1996). The Maria paradox: How Latinas can merge old world traditions with new world self esteem. New York: G. P. Putnam's Sons. 
Ginorio, A. B., \& Martinez, L. J. (1996). Where are the Latinas? Ethno-race and gender in psychology courses. Psychology of Women Quarterly, 22, 53-68.

Gloria, A.M., Castellanos, J., \& Orozco, V. (2005). Perceived educational barriers, cultural fit, coping responses, and psychological well-being of Latina undergraduates. Hispanic Journal of Behavioral Sciences. doi: 10.1177/0739986305275097

Gloria, A.M., Castellanos, J., Scull, N.C., \& Villegas, F.J. (2009). Psychological coping and well being of male Latino undergraduates: Sobreviviendo la universidad. Hispanic Journal of Behavioral Sciences, 31, 317-339. doi: 10.1177/0739986309336845

Gloria, A.M., \& Robinson-Kurpius, S.E. (1996). The validation of the cultural congruity scale and the university environment scale with Chicano/a students. Hispanic Journal of Behavioral Sciences, 18, 533-549. Retrieved from: http://hjb.sagepub.com/

Gloria, A.M. \& Rodriguez, R. (2000). Counseling Latino university students: Psychosociocultural issues for consideration. Journal of Counseling \& Development, 78, 145-154. Retrieved from: http://www.counseling.org/publications/journals.aspx

González, K. (2002). Campus culture and the experiences of Chicano students in a predominantly white university. Urban Education, 37, 193-218.

Goodman, R.D., \& West-Olatunji, C.A. (2010). Educational hegemony, traumatic stress, and African American and Latino American students. Journal of Multicultural Counseling and Development, 38, 176-186. Retrieved from: http://www.counseling.org/Publications/Journals.aspx

Harper, S.R., \& Hurtado, S. (2007). Nine themes in campus racial climates and implications for institutional transformation. New Directions for Student Services, 120, 7-24. Retrieved from: http://dx.doi.org/10.1002/ss.254

Hernandez, J.C. (2000). Understanding the retention of Latino college students. Journal of College Student Development, 41, 575-587. Retrieved from: http://www.jcsdonline.org/

Hernandez, J.C. (2002). A qualitative exploration of the first-year experience of Latino college students. NASPA Journal, 40, 69-84. Retrieved from: http://journals.naspa.org/ jsarp/

Hurtado, S. (1992). The campus racial climate: Contexts for conflict. The Journal of Higher Education, 63(5), 539-569. Retrieved from: http://muse.jhu.edu/journals/journal_of_higher_education/

Hurtado, S., Milem, J.F., Clayton-Pederson, A., \& Allen, W.A. (1996). Enacting diverse learning environments: Improving the campus climate for racial/ethnic diversity in higher education (AHSE-ERIC Series). San Francisco: Jossey-Bass.

Ivey, A.E. \& Ivey, M.B. (1997). Intentional Interviewing and Counseling: Facilitating Client Development in a Multicultural Society. Pacific Grove, CA: Brooks/Cole-Thomson Learning.

Ladson-Billings, G. (1998). Just what is critical race theory and what's it doing in a nice field like education? International Journal of Qualitative Studies in Education, 11(1), 7-24. Retrieved from: http://www.tandf.co.uk/journals/tf/09518398.html

López, G. R. (2001). The value of hard work: Lessons on parent involvement from an (im)migrant household. Harvard Educational Review, 71, 416-437. 
Marín, G., \& Marín, B. (1991). Research with Hispanic populations. Thousand Oaks, CA US: Sage Publications, Inc.

Muñoz, D. G. (1986). Identifying areas of stress for Chicano undergraduates. In M. A. Olivas (Ed.), Latino college students (pp. 131-156). New York: Teachers College Press.

Museus, S.D. (2008). The role of ethnic student organizations in fostering African American and Asian American students' cultural adjustment and membership at predominantly white institutions. Journal of College Student Development, 49, 568-586. doi: 10.1353/csd.0.0039

Nuñez, A-M. (2009). Latino Students' Transitions to College: A Social and Intercultural Capital Perspective. Harvard Educational Review, 79(1), 22-48. Retrieved from: http://her.hepg. org/content/wh7164658k33w477/?p=23e59e61e535495a96193d1e80c5c027\&pi =1

Ojeda, L., Navarro, R. L., \& Morales, A. (2011). The role of la familia on Mexican American men's college persistence intentions. Psychology of Men \& Masculinity, 12, 216-229. doi: 10.1037/a0020091

Pew Hispanic Center (2009). Between Two Worlds: How Young Latinos Come of Age in America. Washington, D.C.: Retrieved on February 1, 2012 from http://pewhispanic.org/files/reports/117.6.pdf

Pinderhughes, E.B. (1997). The interaction of difference and power as a basic framework for understanding work with African Americans: Family theory, empowerment, and educational approaches. Smith College Studies in Social Work, 67, 323-347. doi:10.1080/0037731970951 7496

Reid \& Radhakrishnan, (2003). Race matters: The relationship between race and general campus climate. Cultural Diversity and Ethnic Minority Psychology, 9(3), 263-275. Retrieved from: http: //www.apa.org/pubs/journals/cdp/index.aspx

Rodriguez, N., Mira, C., Myers, H. F., Morris, J. K., \& Cardoza, D. (2003). Family or friends: Who plays a greater supportive role for Latino college students? Cultural Diversity and Ethnic Minority Psychology, 9, 236-250. doi:10.1037/1099- 9809.9.3.236

Sabogal, F., Marín, G., Otero-Sabogal, R., \& Marín, B. V. (1987). Hispanic familism and acculturation: What changes and what doesn't?. Hispanic Journal of Behavioral Sciences, 9, 397-412. doi: $10.1177 / 07399863870094003$

Sánchez, B., Reyes, O., \& Singh, J. (2006). Makin' it in college: The value of significant Individuals in the lives of Mexican American adolescents. Journal of Hispanic Higher Education, 5, 48-67. doi:10.1177/1538192705282570

Santos, S.J. \& Reigadas, E.T. (2002). Latinos in higher education: An evaluation of a faculty-mentoring program. Journal of Hispanic Higher Education, 1(1), 40-50. Retrieved from: http://jhh.sagepub.com/

Solórzano, D.G., \& Delgado Bernal, D. (2001). Examining transformational resistance through a Critical Race and Latcrit theory framework: Chicana and Chicano students in an urban context. Urban Education, 36, 308-342. Retrieved from: http://uex.sagepub.com/

Solórzano, D.G., \& Yosso, T.J. (2001). Critical race methodology: Counter-storytelling as an analytical framework for education. Qualitative Inquiry, 8, 23-44. doi: 10.1177/107780040200800103 
Sue, S. (2003). In defense of cultural competency in psychotherapy and treatment. American Psychologist, 58(11), 964-970. Retrieved from: http://content.apa.org/journ als/amp/58/11/964

Taylor, E. (1998). A primer on critical race theory. Journal of Blacks in Higher Education, 19, 122-124. Retrieved from: http://www.jbhe.com/

Tinto,V. (1975). Dropout from Higher Education: A Theoretical Synthesis of Recent Research. Review of Educational Research, 45, 89-125. Retrieved from: http://muse.jhu.edu/journals/journal_of_higher_education/

Tinto, V. (1993). Leaving College: Rethinking the Causes and Cures of Student Attrition. (2nd ed.). Chicago: University of Chicago Press.

Thile, E., \& Matt, G. (2005). The Ethnic Mentor Undergraduate Program: A Brief Description and Preliminary Findings. Journal of Multicultural Counseling \& Development, 23 (2), 116-126. Retrieved from: http://www.jmcdonline.org/

Torre, M.E. (2008). Participatory action research and critical race theory: Fueling spaces for Nosotros to research. Urban Review, 41, 106-120. doi: 10.1007/s11256-008-0097-7

Torres, J. B., Solberg, V. S. H., \& Carlstrom, A. H. (2002). The myth of sameness among Latino men and their machismo. American Journal of Orthopsychiatry, 72, 163-181.

U.S. Census Bureau (2011). Educational Attainment by Race and Hispanic Origin: 1970 to 2009. Washington, D.C.: Retrieved May 15, 2011, from http://www.census.gov/compendia/statab/2011/tables/11s0225.pdf

Villalpando, O. (1994). Practical consideration of critical race theory and Latino critical theory for Latino college students. New Directions for Student Services, 105(4), 41-50. doi: 10.1002/ss.115

Villalpando, O. (2003). Self-segregation or self-preservation? A critical race theory and Latina/o critical theory analysis of a study of Chicana/o college students. International Journal of Qualitative Studies in Education. 16, 616-646. doi:10.1080/0951839032000142922

Villalpando, O. (2004). Practical considerations of critical race theory and Latino critical theory for Latino college students. New Directions for Student Services, 105, 41-50. doi:10.1002/ss.115

Wells, R. S., Seifert, T. A., Padgett, R. D., Park, S., \& Umbach, P. D. (2011). Why do more women than men want to earn a four-year degree? Exploring the effects of gender, social origin, and social capital on educational expectations. Journal of Higher Education, 82, 1-32. doi: 10.1353/jhe.2011.0004

White, M. (2002). Addressing personal failure. The International Journal of Narrative Therapy and Community Work, 3, 33-70.

Yosso, T., Smith, W., Ceja, M., \& Solórzano, D. (2009). Critical race theory, racial micro aggressions, and campus racial climate for Latina/o undergraduates. Harvard Educational Review, 79, 659-690.

Zell, M.C. (2010). Achieving a college education: Psychological experiences of Latina/o community college students. Journal of Hispanic Higher Education, 9, 167-186. doi: 10.1177/1 538192709343102 